\title{
PENGARUH INFLASI DAN KURS TERHADAP EKSPOR TEH INDONESIA KE JERMAN
}

\author{
Iska Devi ${ }^{a^{*}}$, Murtala $^{\mathrm{a}^{*}}$ \\ ${ }^{a}$ Fakultas Ekonomi dan Bisnis Universitas Malikussaleh \\ *Corresponding author: murtala@unimal.ac.id \\ *iskad33@gmail.com
}

ART I CLE INFORMATION ABSTRACT

Keywords:

Indonesian Tea Exports to Germany, Inflation, Exchange Rates.
- This study aims to determine the effect of inflation and exchange rates on Indonesian tea exports to Germany. The data used in this study are time-series data from 2003 to 2015 obtained from the Central Bureau of Statistics and related agencies. The analytical model used in this study is the Multiple Linear Regression Model. The results of the study partially show that inflation and exchange rates have a positive and significant effect on Indonesian tea exports to Germany. Meanwhile, simultaneously, inflation and exchange rates have no significant effect on Indonesian tea exports to Germany.

\section{PENDAHULUAN}

Indonesia merupakan negara yang sedang berkembang, dimana negara Indonesia banyak melakukan pembangunan disegala bidang untuk mewujudkan masyarakat yang adil dan makmur. Untuk mencapai pembangunan tersebut dibutuhkan pendanaan yang cukup besar. Adanya potensi sumber daya alam yang dimiliki Indonesia dapat menghasilkan keuntungan yang berlimpah serta dapat dimanfaatkan untuk kegiatan perdagangan internasional (Tambunan, 2001)

Perdagangan internasional merupakan akses suatu negara untuk memperluas pangsa pasarnya Salah satu kebijakan pemerintah dalam kegiatan perdagangan antar negara adalah kebijakan impor dan ekspor. Impor merupakan kegiatan dimana sebuah negara memenuhi kebutuhannya dengan cara membeli atau mendatangkan barang dari luar negeri namun tetap dengan aturan dan kebijakan tertentu yang dapat menjaga persaingan dengan barang dalam negeri (Ahsjar, 2007).

Indonesia saat ini telah memasuki ruang lingkup perdagangan yang telah terintegrasi secara internasional. Dilihat dari perkembangan tersebut sektor migas dan nonmigas mengambil peranan yang penting dalam mewujudkan keadaan pertumbuhan ekonomi yang lebih baik (Barudin, 2008).
Tabel 1

Data Inflasi Kurs dan Ekspor Teh Indonesia ke Jerman

\begin{tabular}{|l|l|l|l|}
\hline Tahun & \multicolumn{1}{|c|}{$\begin{array}{c}\text { Ekspor } \\
\text { (ton) }\end{array}$} & $\begin{array}{c}\text { Inflasi } \\
(\boldsymbol{\%})\end{array}$ & \multicolumn{1}{|c|}{$\begin{array}{c}\text { Kurs } \\
(\mathbf{R p})\end{array}$} \\
\hline 2005 & $4.738,8$ & 10,4 & $9.710,64$ \\
\hline 2010 & 5.645 & 6,96 & $9.084,55$ \\
\hline 2013 & $5.131,2$ & 8,38 & $10.451,37$ \\
\hline
\end{tabular}

\section{Sumber : BPS ,BI 2018}

Dapat di lihat dari tabel 1 ekspor, inflasi dan kurs mengalami fluktuatif di setiap tahunnya. Pada tahun 2005 data inflasi sebesar 10,4\% ,kurs Rp 9710,64 dan ekspor sebesar 4738,8 ton. Inflasi merupakan peristiwa moneter yang sering dijumpai dalam perekonomian disuatu negara.

Pada tahun 2010 inflasi mengalami penurunan yaitu menjadi sebesar $6,96 \%$ dan pada kurs mengalami peningkatan yang sangat drastis di bandingkan pada tahun 2005 yaitu sebesar Rp 9084,55 dan juga ekspor mengalami peningkatan sebesar 5654 ton. Pada tahun 2013 inflasi mengalami peningkatan yaitu sebesar $8,38 \%$ dan kurs juga mengalami peningkatan sebesar Rp 10451,37 sedangkan pada ekspor mengalami penurunan sebesar 5131,2 ton. Pada tahun 2013 sama hal nya seperti yang terjadi pada tahun 2005.

Pentingnya kegiatan ekspor menyebabkan perlu dilakukan penelitian lebih lanjut untuk mengetahui inflasi dan kurs apakah dapat 
menyebabkan terjadinya penurunan dan kenaikan ekspor, dalam penelitian ini akan mengkaji ekspor teh indonesia ke jerman.

Adapun tujuan penelitian yang ingin dicapai adalah untuk mengetahui pengaruh inflasi, kurs terhadap ekspor teh Indonesia ke Jerman. Selanjutnya, pada bagian dua, penelitian ini membahas tinjauan teoritis yang terkait dengan variabel-variabel dalam penelitian, kemudian bagian tiga akan memaparkan metode serta alat analisis yang digunakan. Hasil perhitungan dan analisis pembahasan terkait pengaruh inflasi, kurs terhadap ekspor teh Indonesia ke Jerman akan dijelaskan pada bagian empat yang selanjutkan disimpulkan dan diimplikasikan terhadap kebijakan dan saran yang dapat diambil oleh masing-masing pihak terkait.

\section{TINJAUAN TEORITIS}

\section{Ekspor}

Ekspor adalah kegiatan menjual barang dan jasa dari dalam negeri ke luar negeri. Kegiatan ekspor merupakan salah satu cara untuk memasarkan produk Indonesia ke luar negeri. Baik aktivitas ekspor maupun impor memiliki peranan yang sangat penting dalam mendukung laju perdagangan internasional (Bustami, 2013).

\section{Inflasi}

Samuelson (2001) menyatakan bahwa bahwa inflasi adalah suatu keadaan terjadinya kenaikan tingkat harga umum, baik barang-barang, jasa-jasa maupun faktor-faktor produksi dalam periode tertentu.

\section{Kurs ( Nilai Tukar)}

Nilai tukar atau kurs merupakan harga mata uang suatu negara yang dinyatakan dalam mata uang lain yang dapat dibeli dan dijual.

\section{Kerangka Konseptual}

Secara matematis kerangka pemikiran dapat dirumuskan sebagai berikut:

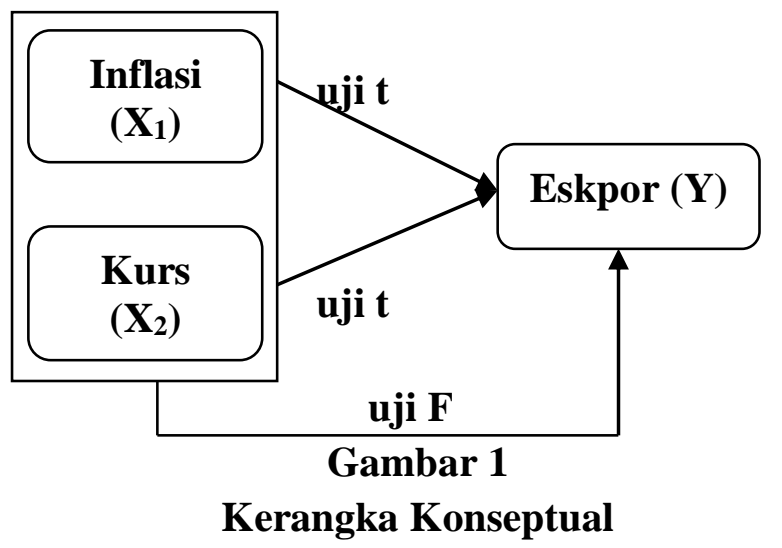

\section{Hipotesis penelitian}

Untuk memberikan kemudahan dalam menganalisi data hasil penelitian dan agar diperoleh analisis penelitian dengan benar dan akurat, maka dibuat kerangka penelitian. Berikut kerangka penelitian :

$\mathrm{H}_{1}$ : Diduga inflasi berpengaruh secara signifikan dan negatif terhadap Ekspor teh indonesia ke Jerman.

$\mathrm{H}_{2}$ : Diduga kurs berpengaruh secara signifikan dan positif terhadap Ekspor teh indonesia ke Jerman.

\section{METODE PENELITIAN}

\section{Data dan Sumber Data}

Penelitian ini menggunakan data sekunder yang berdasarkan runtut waktu (time series) tahunan yaitu dari tahun 2003 hingga tahun 2015 yang diperoleh dari berbagai instansi atau lembaga terkait. Data sekunder yang diperoleh dalam penelitian ini bersumber dari antara lain : Badan Pusat Statistik (BPS), Kementrian perdagangan, Bank Indonesia (BI), Indonesia Tea Board, Uncomtrade dan International Tea Committee (ITC). Data-data yang diperoleh antara lain adalah inflasi,kurs terhadap ekspor teh ke jerman.

\section{Definisi Operasional Variabel}

Pada penelitian ini volume ekspor teh Indonesia ke Jerman dinotasikan Y dalam satuan ton.

Inflasi merupakan keadaan dimana hargaharga cenderung mengalami kenaikkan dan terjadi secara terus menerus. Inflasi yang dimaksud dalam penelitian ini yakni laju inflasi di Indonesia yang dinyatakan dalam persen sebagai variabel $\mathrm{X}_{1}$.

Kurs merupakan alat ukur perbandingan yang digunakan dalam transaksi sebagai 
pembayaran. Nilai tukar yang digunakan adalah kurs Rupiah terhadap Euro Jerman berdasarkan kurs tengah yang dihitung berdasarkan kurs jual dan kurs beli yang telah diatur oleh Bank Indonesia. Dalam penelitian ini kurs dinotasikan $\mathrm{X}_{2}$ dalam satuan ribu Rupiah.

\section{Metode Analisis Data}

Penelitian ini menganalisis Pengaruh dan hubungan Luas lahan, Produksi, Harga Internasional terhadap Ekspor Kakao Indonesia dengan menggunakan dua metode analisis yaitu :

\section{Regresi Linier Berganda}

Penelitian ini menggunakan analisis regresi linear berganda karena variabel bebasnya lebih dari satu variabel,untuk mengetahui pengaruh inflasi dan kurs terhadap ekspor teh indonesia ke jerman maka menggunakan persamaan sebagai berikut:

$$
Y=a+\beta_{1} X_{1}+\beta_{2} X_{2}+e
$$

Dimana :

$$
\begin{array}{ll}
\mathrm{Y} & : \text { Ekspor teh } \\
\mathrm{a} & : \text { Konstanta } \\
\beta_{1} \beta_{2} & : \text { Koefisien Regresi Variabel } \\
\mathrm{X}_{1} & : \text { Inflasi } \\
\mathrm{X}_{2} & : \text { Kurs } \\
\mathrm{e} & \text { : Variabel penganggu (Standar Erorr) }
\end{array}
$$

Sedangkan untuk mengetahui tingkat signifikan pada masing-masing koefisien regresi variabel bebas terhadap variabel terikat maka peneliti menggunakan uji, normalitas, uji asumsi klasik, uji t-statistik, uji F-statistik, dan analisis koefisien determinasi $\left(\mathrm{R}^{2}\right)$.

\section{Uji Normalitas}

Uji normalitas bertujuan untuk mengetahui apakah data sudah menyebar secara normal dan mengetahui kenormalan error term dari variabel bebas maupun terikat. Jika data tidak terdistribusi normal maka hasilnya tetap tidak bias, namun tidak lagi efisien. Metode yang digunakan dalam uji normalitas ini dapat menggunakan metode Jarque-Bera Test (J-B Test). Hipotesis yang digunakan adalah:

Ho : Data berdistribusi normal

Ha : Data tidak berdistribusi normal

Kriteria pengujian: a. Ho ditolak, jika nilai probabilitas $<\alpha 5 \%$. Artinya bahwa residual mempunyai distribusi normal karena nilai statistik J-B tidak sama dengan nol.

b. Ho diterima, jika nilai probabilitas $>\alpha 5 \%$. Artinya bahwa residual mempunyai distribusi normal karena nilai statistik J-B mendekati nol.

\section{Pengujian Asumsi Klasik \\ Uji Autokorelasi}

Pengujian ini bertujuan untuk mengetahui ada atau tidaknya korelasi antara data dalam variabel pengamatan. Untuk mendeteksi adanya autocorelasi dapat digunakan metode Breusch-Godfrey dan sering dikenal dengan nama metode Lagrange Multiplier (LM). Metode ini merupakan pengembangan dari metode Durbin-Watson.

Hipotesis yang digunakan untuk menguji ada tidaknya autocorelasi yaitu :

a. Ho ditolak, jika Obs*R-squared ( $\chi^{2}$ hitung) $>$ ( $\chi^{2}$ tabel), atau probabilitasnya $<\alpha=0.05$. Ini menunjukkan adanya masalah autocorelasi didalam model.

b. Ho diterima, jika Obs*R-squared ( $\chi^{2}$ hitung) < ( $\chi^{2}$ tabel), atau probabilitas $>\alpha=0.05$. Ini menunjukkan tidak adanya masalah autocorelasi dalam model.

\section{Uji Heteroskedastisitas}

Pengujian ini bertujuan untuk mengetahui apakah dalam model regresi terjadi ketidaksamaan varian dari residual pengamatan lain. Karena heteroskardasitas terjadi ketika varians dari residual pengamatan satu ke residual pengamatan yang lain tetap. Untuk mendeteksi ada atau tidaknya heteroskardasitas dapat dilihat melalui Uji White. Dalam pengujian heteroskardasitas Uji White merumuskan hipotesis sebagai berikut :

Ho : tidak terdapat heteroskardasitas

$\mathrm{Ha}:$ terdapat heteroskardasitas

Kriteria pengujian heteroskardasitas adalah :

a. Ho ditolak, jika nilai Obs*R square ( $\lambda^{2}$ hitung $)>$ $\lambda^{2}$ tabel. Maka terdapat masalah heteroskardasitas.

b. Ho diterima, jika nilai Obs*R square ( $\lambda^{2}$ hitung) $<\lambda^{2}$ tabel. Maka tidak ada masalah heteroskardasitas.

Selain itu dapat dilihat juga apabila nilai probabilitas Obs*R square lebih besar dari $\alpha(5 \%)$ maka data bersifat heteroskardasitas. Sebaliknya bila probabilitas Obs*R square lebih kecil dari $\alpha(5 \%)$ maka bersifat tidak heteroskardasitas. 


\section{Uji Multikolinearitas}

Uji multikolineritas digunakan untuk mengetahui adanya hubungan linier antar variabel dependent dalam model regresi atau untuk menguji ada tidaknya hubungan yang sempurna atau tidak sempurna diantara beberapa atau semua variabel yang menjelaskan. Ada beberapa cara untuk menganalisis ada atau tidaknya pengaruh multikolineritas dalam penelitian ini yaitu :

a. $\mathrm{R}^{2}$ relatif tinggi $(0,70-1,00)$ tetapi hanya sebagian kecil atau bahkan tidak ada variabel bebas yang signifikan menurut t-test, maka diduga terdapat multikolineritas.

b. Koefisien determinasi individual $\left(\mathrm{r}^{2}\right)$ relatif tinggi dari pada koefisien determinasi serentak $\left(\mathrm{R}^{2}\right)$, maka cenderung terdapat multikolineritas.

c. Mengamati nilai Varians Inflation Factor (VIF) pada model regresi, jika VIF $\geq 10$ maka terjadi multikolineritas.

Pada penelitian ini dalam mendeteksi gejala multikolineritas adalah dengan mengamati nilai Varians Inflation Factor (VIF) pada model regresi. Suatu data dapat dikatakan terbebas dari gejala multikolineritas jika nilai VIF antar variabel independent lebih kecil dari 10.

\section{Pengujian Statistik}

Untuk menguji kebenaran model regresi diperlukan pengujian statistik diantaranya :

\section{Uji t-statistik}

Uji t-statistik dilakukan untuk menjelaskan pengaruh variabel bebas secara individu memberikan pengaruh atau tidak terhadap variabel terikat. Dengan menggunaka derajat signifikan $5 \%$, hipotesis yang akan diuji dalam penelitian ini adalah :

$\mathrm{H}_{1}$ : Diduga inflasi berpengaruh secara signifikan dan negatif terhadap Ekspor teh indonesia ke Jerman.

$\mathrm{H}_{0}$ : Diduga inflasi tidak berpengaruh secara signifikan dan positif terhadap Ekspor teh indonesia ke Jerman

$\mathrm{H}_{2}$ : Diduga kurs berpengaruh secara signifikan dan positif terhadap Ekspor teh indonesia ke Jerman.

$\mathrm{H}_{0}$ : Diduga kurs tidak berpengaruh secara signifikan dan negatif terhadap Ekspor teh indonesia ke Jerman.
Kriteria uji t-statistik, $\mathrm{H}_{1}$ di terima dan $\mathrm{H}_{0}$ di tolak jika nilai t-statistik lebih besar dari nilai ttabel $a=5 \%$ dan sebaliknya.

\section{Uji F-statistik}

Uji ini digunakan untuk mengetahui pengaruh variabel independen secara signifikan terhadap variabel dependen. Dimana jika $\mathrm{F}_{\text {hitung }}>$ $\mathrm{F}_{\text {tabel, }}$ maka $\mathrm{H}_{1}$ diterima atau variabel dependen. Sebaliknya jika $F_{\text {hitung }}<\mathrm{F}_{\text {tabel}}$, maka $\mathrm{H}_{0}$ diterima variabel independen secara bersama-sama tidak memiliki pengaruh terhadap variabel dependen (tidak signifikan) dengan kata lain perubahan yang terjadi pada variabel terikat tidak dapat dijelaskan oleh perubahan variabel independen, dimana tingkat signifikan yang digunakan adalah 5\%.

\section{Uji Koefisien Determinasi $\left(\mathbf{R}^{\mathbf{2}}\right)$}

Pada $\mathrm{R}^{2}$ diartikan besarnya presentase sumbangan variabel bebas $(\mathrm{X})$ terhadap variasi (naik-turunnya) variabel terikat (Y) sedangkan lainnya merupakan sumbangan dari faktor lainnya yang tidak termasuk dalam model (Rahim, 2013).

Koefisien determinasi $\left(\mathrm{R}^{2}\right)$ digunakan untuk mengukur seberapa jauh kemampuan model dalam menerangkan variasi variabel terikat. Nilai koefisien determinasi adalah antara 0 dan 1 . Nilai $\mathrm{R}^{2}$ yang kecil berarti kemampuan variabel-variabel bebas dalam menjelaskan variasi variabel terikat amat terbatas.

\section{HASIL DAN PEMBAHASAN Hasil Penelitian}

Berikut ini akan dipaparkan hasil penelitian melalui hasil uji yang telah dilakukan dengan alat analisis yang telah ditentukan untuk melihat pengaruh inflasi dan kurs terhadap ekspor teh Indonesia ke Jerman.

\section{Uji Normalitas}

Menurut Widarjono, (2009) Jika nilai Jarque Berra $(J B)>\alpha=5 \%(0,05)$, maka berdistribusi normal. Setelah di lakukan pengujian dengan menggunakan E-eviews, maka di peroleh hasil sebagai berikut : 




Sumber : Data diolah,2019

\section{Gambar 2. Histogram - Uji Normalitas}

Gambar 2 menunjukkan bahwa nilai JB hitung sebesar 4,591801 dan nilai kepercayaan $a=$ 5\% (0,05).Dengan JB hitung $(4,591801)>$ nilai $a$ $(0,05)$ dan dapat di simpulkan bahwa data penelitian ini berdistribusi normal.Selain itu dapat di lihat dari nilai probabilitas yang lebih besar dari $a=5 \%(0,05)$, dengan nilai probabilitas sebesar 0,100671 .

\section{Uji Asumsi Klasik}

\section{Uji Autokorelasi}

Dalam penelitian ini pengujian autikorelasi menggunakan metode Lagrange Multiplier Test (LM) dengan lag residual yang digunakan yaitu lag 3 untuk mengetahui apakah dalam model penelitian, variabel terbebas dari autokorelasi maka dapat di ketahui dengan melihat dan membandingkan nilai Probability Chi-Square dengan nilai kepercayaan $a=5 \%(0,05)$. Menurut Widarjono (2009), Jika nilai probability Chi Square $>a=5 \%(0,05)$, maka data terbebas dari autokorelasi. Hasil yang diperoleh adalah sebagai berikut:

Tabel 2

Uji Autokorelasi

\begin{tabular}{|l|l|l|l|}
\hline F-statistic & 2.138644 & Prob. F(3,7) & 0.1836 \\
\hline $\begin{array}{l}\text { Obs }{ }^{\star} \text { R- } \\
\text { squared }\end{array}$ & 6.217020 & $\begin{array}{c}\text { Prob. Chi- } \\
\text { Square(3) }\end{array}$ & 0.1015 \\
\hline
\end{tabular}

\section{Sumber : Data diolah,2019}

Tabel 2 menunjukkan bahwa nilai Prob.Chi-Square sebesar 0,1015, dan nilai kepercayaan $a=5 \%(0,05)$. Dengan nilai Prob .Chi-Square $(0,1015)>a=5 \%(0,05)$ dan dapat di simpulakan bahwa data penelitian terbebas dari autokorelasi.

\section{Uji Heteroskedastisitas}

Setelah di lakukan pengujian maka hasil yang di peroleh adalah sebagai berikut:

\section{Tabel 3}

Uji Heteroskedastisitas dengan Metode Glejser

\begin{tabular}{|c|c|c|c|c|}
\hline \multicolumn{2}{|c|}{ Test Equation: } & & & \\
\hline \multicolumn{3}{|c|}{ Dependent Variabel: ARESID } & & \\
\hline \multicolumn{5}{|c|}{ Method: Least Squares } \\
\hline \multicolumn{5}{|c|}{ Date: $06 / 07 / 19$ Time: $14: 07$} \\
\hline \multicolumn{5}{|c|}{ Sample: 20032015} \\
\hline \multicolumn{5}{|c|}{ Included observations: 13} \\
\hline Variabel & Coefficient & Std. Error & $\mathrm{t}$-Statistic & Prob. \\
\hline C & 278.2374 & 1840.788 & 0.151151 & 0.8829 \\
\hline INFLASI & -1.960972 & 72.31535 & -0.027117 & 0.9789 \\
\hline KURS & 0.041207 & 0.167103 & 0.246595 & 08102 \\
\hline
\end{tabular}

\section{Sumber:Data diolah,2019}

Pada tabel 3 di ketahui nilai probabilitas variabel inflasi $(0,9789)>a=5 \%,(0,05)$, nilai probability dari variabel kurs $(0,8102)>a=5 \%$ $(0,05)$.maka pada penelitian ini dapat di simpulkan terbebas dari Heteroskedastisitas.

\section{Uji Multikolinearitas}

Menurut Hamja (2012) untuk mengidentifikasi masalah multikolinearitas dapat di lihat dari nilai matriks korelasi,dimana nilainya tidak boleh kecil dari 0,8 adapun hasil yang di peroleh sebagai berikut:

Tabel 4

Uji Multikolinearitas dengan Matriks Korelasi

\begin{tabular}{|c|c|c|}
\hline & INFLASI & KURS \\
\hline INFLASI & 1 & -0.20664317004361 \\
\hline KURS & -0.20664317004361 & 1 \\
\hline
\end{tabular}

Sumber : Data diolah,2019

Dari tabel di atas dapat di ketahui bahwa tidak terdapat masalah multikolinearitas karena nilai matriks korelasi semua variabel independen( inflasi, kurs) kurang dari nilai $<0,8$.

\section{Uji Hipotesis}

pengujian ini lakukan untuk mengetahui hipotesis yang telah di tetapkan di terima atau di tolak secara statistik. Pengujian statistik di lakukan dengan uji T,uji F dan uji $\mathrm{R}^{2}$. Adapun model yang di gunakan merupakan regresi data sekunder dengan menggunakan Ordinary Least Square $(O L S)$ dan hasil yang di dapatkan sebagai berikut: 
Tabel 5

Dependent Variabel: EKSPOR

Method: Least Squares

Date: 06/06/19 Time: 19:37

Sample: 20032015

Included observations: 13

\begin{tabular}{crrrr}
\hline \hline Variabel & Coefficient & Std. Error & t-Statistic & Prob. \\
\hline \hline C & 7605.090 & 2584.922 & 2.942096 & 0.0147 \\
INFLASI & 64.16078 & 101.5487 & 0.631823 & 0.5417 \\
KURS & -0.277879 & 0.234653 & -1.184209 & 0.2637 \\
\hline
\end{tabular}

Sumber : data diolah 2019

$($ Ekspor teh $)=7605.090+64.16078$ (Inflasi) -0.277879 (Kurs) $+e$

1) Konstanta $(C)=7605.090$, Pada saat Inflasi dan Kurs maka Ekspor teh tetap konstan sebesar 7605.090 .

2) Inflasi $=64.16078$,jika inflasi meningkat $1 \%$ maka akan menyebabkan Ekspor teh meningkat sebesar $64 \%$.

3) Kurs $=-0,277879$, jika Kurs meningkat $1 \mathrm{Rp}$ maka akan menyebabkan Ekspor teh menurun sebesar 0,27 Rp.

\section{Uji -t dan interprestasi}

Pengujian ini di lakukan untuk melihat apakah variabel independen (inflasi, kurs) berpengaruh secara parsial (individu) terhadap variabel (independen) dengan kata lain uji ini untuk melihat masing - masing variabel bebas terhadap variabel terikat.

Kemudian membandingkan masing masing nilai t-statistik dari hasil regresi dengan nilai t-tabel dan di simpulkan dengan hipotesis.Pada tingkat signifikan $a=5 \%$ maka di peroleh t-tabel.

\section{Tabel 6}

\section{Hasil uji -t}

\begin{tabular}{|c|c|c|c|}
\hline Variabel & t-statistik & t-tabel & Prob \\
\hline C & 2,942096 & 2,22814 & 0,0147 \\
\hline Inflasi & 0,631823 & 2,22814 & 0,5417 \\
\hline Kurs & -184209 & 2,22814 & 0,2637 \\
\hline
\end{tabular}

Sumber : data diolah,2019

\section{1) Inflasi}

Setelah melihat hasil tabel 6 diketahui bahwa t-statistik dari variabel inflasi sebesar 0,631823, sedangkan nilai t-tabel 2,22814. Dengan hipotesis:
$\mathrm{H}_{0}: \beta=0$, berarti secara parsial tidak ada pengaruh signifikan dari variabel inflasi terhadap ekspor teh Indonesia ke Jerman.

$\mathrm{H}_{\mathrm{a}}: \beta \neq 0$, berarti secara parsial ada pengaruh yang signifikan dari variabel inflasi terhadap variabel ekspor teh Indonesia ke Jerman.

Karena t-statistik $(0,631823)<\mathrm{t}$-tabel $(2,22814)$ yang berarti $\mathrm{H}_{0}$ di terima maka dapat di simpulkan bahwa secara parsial tidak ada pengaruh signifikan antara variabel inflasi dengan variabel ekspor teh Indonesia ke jerman. Hasil ini di perkuat dengan probabilitas inflasi $(0,5417)>a$ $=5 \%$ (0,05). Maka dapat di simpulkan bahwa secara parsial variabel inflasi berpengaruh secara negatif dan signifikan terhadap variabel ekspor the Indonesia ke Jerman.

\section{2) Kurs}

Setelah melihat hasil dari tabel 5 diketahui bahwa t-statistik dari variabel kurs sebesar 1.84209, sedangkan nilai t-tabel 2,22814. Dengan hipotesis:

$\mathrm{H}_{0}: \beta=0$, berarti secara parsial tidak ada pengaruh signifikan dari variabel kurs terhadap ekspor teh Indonesia ke Jerman.

$\mathrm{H}_{\mathrm{a}}: \beta \neq 0$, berarti secara parsial ada pengaruh yang signifikan dari variabel kurs terhadap variabel ekspor teh Indonesia ke Jerman.

Karena t-statistik $(-1,84209)<\mathrm{t}$-tabel $(2,22814)$ yang berarti $\mathrm{H}_{0}$ diterima. Maka dapat di simpulkan bahwa secara parsial tidak ada pengaruh signifikan antara variabel kurs terhadap ekspor teh Indonesia ke Jerman. Hasil ini di perkuat dengan nilai probabilitas kurs $(0,2637)>0$ $=5 \%(0,05)$. Maka dapat di simpulkan secara parsial variabel kurs ada pengaruh signifikan dan negative terhadap variabel ekspor teh Indonesia ke Jerman.

\section{Uji F dan Interprestasi}

Pengujian ini dilakukan untuk mengetahui dan melihat pengaruh antara variabel independen (inflasi dan kurs) terhadap variabel dependen (ekspor teh Indonesia ke Jerman) dari hasil regresi diperoleh nilai F-statistik sebesar 1.102456. pada tingkat signifikansi $a=5 \%, \mathrm{k}=3, \mathrm{n}=$ 13,sehingga di peroleh F-tabel dengan nilai df yaitu 4,10 . 
Tabel 7

Hasil uji F

\begin{tabular}{|c|c|}
\hline F-statistik & 1,102465 \\
\hline Prob (F-statistik) & 0,369252 \\
\hline
\end{tabular}

\section{Sumber :data diolah 2019}

Dengan hipotesis :

$\mathrm{H}_{0}: \beta=0$, berarti tidak ada pengaruh signifikan dari variabel inflasi,kurs terhadap ekspor teh Indonesia ke Jerman secara simultan (sama sama).

$\mathrm{H}_{\mathrm{a}}: \beta \neq 0$,berarti ada pengaruh yang signifikan dari variabel inflasi,kurs terhadap ekspor teh Indonesia ke Jerman secara simultan (sama sama).

Diketahui bahwa nilai F-statistik ( 1,102465) < F tabel $(4,10)$ maka dapat di simpulkan bahwa secara simultan variabel inflasi, kurs tidak ada pengaruh signifikan terhadap ekspor teh Indonesia ke Jerman.

\section{Uji Koefisien Determinasi $\left(\mathbf{R}^{2}\right)$ dan Interprestasi}

Berdasarkan pengolahan data dengan menggunakan Eviews diperoleh nilai $\mathrm{R}^{2}$ sebesar 0,016791.nilai ini menjelaskan bahwa $0,16 \%$ variabel ekspor teh Indonesia ke Jerman mampu di jelaskan oleh variabel inflasi dan kurs sedangkan 84\% variabel ekspor teh Indonesia ke Jerman dapat di jelaskan oleh variabel lain yang tidak termasuk dalam penelitian.

\section{Pembahasan}

\section{Pengaruh Inflasi terhadap Ekspor Teh Indonesia ke Jerman}

Berdasarkan hasil regresi penelitan pada tabel 5 dapat disimpulkan bahwa secara parsial inflasi tidak berpengaruh dan signifikan terhadap ekspor teh Indonesia ke Jerman. Hal ini sejalan dengan hasil penelitian dari Ansharia, Khillab, \& Permata, (2017) yang menyatakan secara parsial, variabel inflasi tidak berpengaruh secara signifikan di negara Indonesia, Malaysia, Singapura, dan Thailand.

\section{Pengaruh Kurs terhadap Ekspor Teh Indonesia ke Jerman}

Berdasarkan hasil regresi penelitan pada tabel 5 dapat disimpulkan bahwa secara parsial kurs berpengaruh secara signifikan dan negatif terhadap ekspor teh Indonesia ke Jerman. Hal ini sejalan dengan hasil penelitian yang dilakukan oleh Ansharia et al., (2017) yang menyatakan bahwa secara parsial, variabel kurs berpengaruh secara negatif terhadap ekspor di negara Indonesia, Malaysia, dan Singapura.

\section{KESIMPULAN DAN SARAN}

\section{Kesimpulan}

Berdasarkan hasil penelitian dan pembahasan dapat di ambil kesimpulan sebagai berikut:

1. Berdasarkan uji Parsial variabel Inflasi karena t-statistik $(0,631823)<$ tabel $(2,22814)$ yang berarti H0 di terima. maka dapat di simpulkan bahwa secara parsial ada pengaruh signifikan dan negatif antara variabel inflasi dengan variabel ekspor teh Indonesia ke jerman. Hasil ini di perkuat dengan probabilitas inflasi $(0,5417)>a$ $=5 \%(0,05)$. Maka dapat di simpulkan bahwa secara parsial variabel inflasi tidak berpengaruh dan signifikan terhadap variabel ekspor teh Indonesia ke Jerman.

2. Berdasarkan uji Parsial variabel Kurs karena t-statistik $(-1,84209)<$ t-tabel $(2,22814)$ yang berarti HO diterima. Maka dapat di simpulkan bahwa secara parsial ada pengaruh signifikan antara variabel kurs terhadap ekspor teh Indonesia ke Jerman. Hasil ini di perkuat dengan nilai probabilitas kurs $(0,2637)>a=5 \%(0,05)$. Maka dapat di simpulkan secara parsial variabel kurs ada pengaruh signifikan dan negatif terhadap variabel ekspor teh Indonesia ke Jerman.

3. Berdasarkan uji simultan (sama-sama) dapat diketahui bahwa nilai F-statistik ( 1,102465) < F tabel $(4,10)$ maka dapat di simpulkan bahwa secara simultan variabel inflasi,kurs tidak ada pengaruh signifikan terhadap ekspor teh Indonesia ke Jerman.

4. Berdasarkan uji Determinasi $\left(\mathrm{R}^{2}\right)$ pengolahan data dengan menggunakan Eeviews 9.0 diperoleh nilai $\mathrm{R}^{2}$ sebesar 0,016791.nilai ini menjelaskan bahwa $0,16 \%$ variabel ekspor teh Indonesia ke Jerman mampu di jelaskan oleh variabel 
inflasi dan kurs sedangkan $84 \%$ variabel ekspor teh Indonesia ke Jerman dapat di jelaskan oleh variabel lain yang tidak termasuk dalam penelitian.

\section{Saran}

Dari kesimpulan di atas, maka saran-saran yang dapat di ajukan dari hasil temuan penelitian ini adalah sebagai berikut:

1. Petani teh perlu meningkatkan kualitas produksi teh Indonesia untuk dapat bersaing di pangsa pasar dunia serta perlu adanya sertifikat mutu terhadap teh indonesia sehingga dapat menjamin konsumen dan meningkatkan nilai jual teh Indonesia.

2. Dengan adanya kebijakan yang tepat melalui peningkatan ekspor teh di harapkan total ekspor Indonesia mengalami peningkatan dan menambah pendapatan nasional melalui devisa yang di peroleh tanpa terjadi inflasi.

3. Bagi akademisi yang bermaksud melakukan penelitian lebih lanjut,di sarankan agar memperluas objek penelitian pada variabel-varabel lainnya yang memiliki kaitan dengan volume ekspor teh Indonesia ke Jerman.

\section{DAFTAR PUSTAKA}

Ansharia, M. F., Khillab, A. El, \& Permata, I. R. (2017). ANALISIS PENGARUH INFLASI DAN KURS TERHADAP EKSPOR DI NEGARA ASEAN 5. 121-128.

Artika, R. (2017). Pengaruh nilai tukar rupiah ,produksi domestik kakao,dan luas lahan terhadap ekspor ekspor kakao indonesia tahun 1995- 2015

Berata, I. K. E. W., \& Setiawina, N. D. (2013). Pengaruh luas lahan,jumlah produksi ,kurs dollar Amerika Serikat dan Inflasi terhadap ekspor kakao Indonesiankurun waktu 19942013

Boubakri, S., Guillaumin, C., \& Silanine, A. (2019). Non-linear relationship between real commodity price volatility and real effective exchange rate: The case of commodityexporting countries. Journal of Macroeconomics. https://doi.org/10.1016/j.jmacro.2019.02.004

Chen, P., Zeng, J., \& Lee, C. (2018). NU SC. China Economic Review. Elsevier Inc. https://doi.org/10.1016/j.chieco.2018.03.009

Chi, J., \& Keow, S. (2016). Do exchange rate volatility and income affect Australia's maritime export fl ows to Asia? Transport Policy, 47 , $13-21$. https://doi.org/10.1016/j.tranpol.2015.12.003

Fani, R., \& Putri, A. (2011). Komoditi tekstil dan elektonika ke Korea Selatan ( Studi Sebelum dan Setelah ASEAN Korea Free Trade Agreement Tahun 2011 ), 35(1), 127-136.

I, I. G. Y. M., Kesumajaya, I. W. W., \& Fakultas. (2015). Analisis pengaruh investasi,kurs dollar Amerika Serikat dan suku bunga kredit terhadap ekspor Indonesia tahun 1992-2012, 525-545.

Iacovone, L., Ferro, E., Pereira-lópez, M., \& Zavacka, V. (2019). Banking crises and exports: Lessons from the past. Journal of Development Economics. https://doi.org/10.1016/j.jdeveco.2018.12.005

Pratama, I. M. D., Bendesa, I. K. ., \& Jurusan. (2012). Analisis faktor -faktor yang mempengaruhi nilai ekspor kerajinan kerang di provinsi Bali.313-325.

Purba, J. H. V, \& Magdalena, A. (2017). PENGARUH NILAI TUKAR TERHADAP EKSPOR DAN DAMPAKNYA TERHADAP PERTUMBUHAN EKONOMI INDONESIA. 12(2), 285-295.

Putra, A. A. N. A. M., \& Yasa, I. N. M. (2016). Pengaruh inflasi dan pertumbuhan ekonomi terhadap kurs dollar Amerika Serikat dan ekspor Indonesia

Astuti, I. P., \& Ayuningtyas, F. J. (2018). PENGARUH EKSPOR DAN IMPOR TERHADAP PERTUMBUHAN EKONOMI DI INDONESIA. 19(April). https://doi.org/10.18196/jesp.19.1.3836

Schumacher. (2013). Analisis pengaruh investasi, 
inflasi,kurs dollar Amerika Serikat dan sukubunga kredit terhadap ekspor indonesia tahun 1992-2012.

Smallwood, A. D. (2019). AC. Economic Modelling.

https://doi.org/10.1016/j.econmod.2019.01.01 4

Sonia, A. P., \& Setiawina, N. D. (n.d.). Pengaruh kurs , Jub dan tingkat inflasi terhadap ekspor,impor dan cadangan devisa indonesia,1077-1102.

Sun, J., Yang, G., Liang, Y., Chen, Y., \& Sun, J. (2014). Experimental Study of Boundary Layer Effect on the Aeroacoustic Characteristics of the Incompressible Open Cavity. AASRI Procedia, 9(Csp), 158-164. https://doi.org/10.1016/j.aasri.2014.09.025

Tambunan. (2001) Analisis pengaruh investasi,inflasi,kurs dollar Amerika Serikat dan suku bunga kredit terhadap ekspor indonesia tahun 1992-2012.

Thornton, J., \& Vasilakis, C. (2019). PT US CR. Finance Research Letters. https://doi.org/10.1016/j.frl.2019.03.023 